\title{
The Role of Tax Incentives in Facing the Economic Downturn Amid the Covid 19 Pandemic
}

\author{
Dyah Adriantini Sinta Dewi ${ }^{1}$, Habib Muhsin Syafingi ${ }^{2}$, Dilli Trisna Noviasari ${ }^{3}$ \\ \{dyahasd@ummgl.ac.id ${ }^{1}$ \} \\ Department of Constitutional Law, Faculty of Law, Universitas Muhammadiyah Magelang, Magelang, \\ Indonesia ${ }^{1,2,3}$
}

\begin{abstract}
The Covid-19 pandemic has weakened the national economic sector. Not only Indonesia, the weakness in this sector was also felt by other countries. The government has returned to designing a strategy so that the economic recovery can run quickly. This is evidenced by data from BPS which records that household consumption fell from 5.02 percent in the first quarter of 2019 to 2.84 percent in the first quarter of this year. The second impact, namely the pandemic, causes prolonged uncertainty so that investment also weakens and has implications for the cessation of business. The third impact is that the entire world is experiencing a weakening economy, causing commodity prices to fall and Indonesian exports to several countries to stop. Tax incentives are one of the policy steps that the Therefore, this tax incentive regulation needs to be reviewed in terms of optimizing the empowerment of the business sector so that they can survive during the Covid 19 pandemic as it is today. To achieve this objective, this study uses an exploratory approach. With a qualitative exploratory method, this research produces analytical exploratory data. Activities in analyzing this include reducing the data obtained by looking at the concept and development of the application of tax incentives given to entrepreneurs in the midst of the Covid 19 pandemic and then comparing the benefits for entrepreneurs in maintaining their businesses in order to survive.
\end{abstract}

Keywords: Economy, covid-19, tax incentives

\section{Introduction}

In 2020, this is a tough year for the Indonesian people. This is because the Covid-19 pandemic that hit the world, including in Indonesia, has had a huge impact on all aspects of people's lives, especially in the health and economy sectors. In the health sector every day we always hear bad news. Indonesian citizens who are exposed to Covid-19 are increasing day by day, even though on the other hand, the number of recovered patients is also increasing. Not only in the health sector, the people's economy was also greatly affected by the sluggish economic growth during this pandemic. Many employers have gone out of business, even almost every day there are employees who are laid off, causing an increase in the number of unemployed. The government's economic growth target at the beginning of the year of 5.3 percent with an inflation rate of 3.1 percent is unlikely to be realized this year.

Various efforts have been made by the government to increase sluggish economic growth, one of which is in the taxation sector. The government through the Minister of Finance issued the Minister of Finance Regulation Number 23 of 2020 concerning Tax Incentives for Taxpayers 
Affected by the Covid-19 Virus Outbreak. The provision of this incentive is a response from the government to the taxpayer's economy, which has dropped dramatically due to the pandemic. In accordance with this regulation, the incentives provided by the government are value added tax (VAT) and income tax (PPh).

First, the incentive value added tax (VAT) is not collected and value added tax (VAT) is borne by the government (VAT DTP). This is expected to provide a stimulus to the business world that is being affected by this pandemic. Second, the exemption of income tax $(\mathrm{PPh})$ article 22 on imports or purchases of goods for handling Covid-19 by certain parties. Then, the exemption of Article 23 income tax $(\mathrm{PPh})$ for domestic corporate taxpayers and permanent establishments (BUT). Then, the Article 21 income tax (PPh) exemption for individual domestic taxpayers who receive compensation from certain parties as compensation for providing services needed in the context of handling the Covid-19 pandemic. The provision of this incentive will last for six months, from April to September 2020. This means that after this regulation is passed, the submission of tax returns for the April to September 2020 period will begin to apply incentives to taxpayers who carry out the tax obligations stated in the ministerial regulation. finance (PMK).

In addition, to deal with domestic supply chain disruptions caused by slowing global economic growth due to the Covid-19 pandemic, the government provides incentives for companies receiving bonded zone facilities and / or ease of import for export purposes (KITE) as stipulated in PMK Number 31 / PMK. 04/2020 concerning Additional Incentives for Companies Recipient of Bonded Zone Facilities and or Ease of Import for Export Purposes for Handling the Impact of the Corona Virus Disease 2019 / Covid-19 Disaster. There is the hope of the state to maintain national economic growth while maintaining the business sector in Indonesia, therefore it is necessary to study the effectiveness of the carrying capacity of tax incentives in helping entrepreneurs in Indonesia to survive the current pandemic situation.

\section{Method}

This study uses an exploratory method. Regulations regarding taxation and aspects that affect the weakening of the national economy including the resilience of Indonesian businessmen will be explored and linked to the benefits of providing tax incentives by the government during the Covid 19 pandemic on the capacity to sustain the survival of businesses in Indonesia. After finding a balanced variable between the regulations regarding tax incentives and their benefits, it will be concluded how the carrying capacity of these regulations on the empowerment of entrepreneurs in Indonesia in maintaining their business during the Covid 19 pandemic.

\section{Results and Discussion}

The Corona Virus Disease 2019 (Covid-19) outbreak is a national disaster that affects national economic stability and community productivity. The Covid 19 pandemic has an impact on every aspect of life, be it social, political and economic, both national and international. All countries have experienced the impact of this disaster, so the government has paid attention to various sectors to be able to suppress the existence of a national economic slowdown. 
There is a different system between corporate taxpayers whose status is UMKM and normal corporate taxpayers. This difference starts from the type of tax reporting letter, the amount of the tax rate, to the incentives provided by the government [1]. The tax incentive policies introduced by the government during the Corona or Covid-19 pandemic are considered relatively complete in maintaining the sustainability of the business world.

The government is trying to provide tax relief for businesses amidst domestic and global economic pressures. Estimated figures in 2018, the government provides tax incentives from income tax exemptions, free VAT, and free imported goods. The incentive is equivalent to 1.5 percent of gross domestic product (GDP). This figure can add to the tax ratio. If the tax ratio is 11 percent and the incentive is 1.5 percent, the potential tax on GDP could actually be 12.5 percent. Indonesia's tax ratio is already high. This achievement is the government's move to encourage tax collection by preparing tax incentives. The government, in this case, has also prepared many incentives for both the upstream industry, which are expected to benefit the downstream industry. Then the downstream industry has also prepared various incentives [2].

The tax incentives issued include exemption from Income Tax (PPh), Value Added Tax (PPN), to exemption from import duty on imports of certain goods. In 2018, fiscal incentives that have been provided by the government, such as tax holidays and tax allowances, are stated in the Minister of Finance Regulation Number 35 of 2018. Academics and consultants from Precious Nine Consulting assess that giving tax incentives is one of the government's realistic steps to maintain the sustainability of the business. However, the tax burden will also be relatively heavy if there is a surge in taxpayers with overpayment of tax payments to the state treasury. As a result, the work of tax officers will be drained for examining overpayment claims from taxpayers [3].

The Covid-19 pandemic that has occurred since the beginning of 2020 has put enormous pressure on world conditions, especially in the economic and health sectors. The latest 2020 global economic growth projections are negative or in recession. JP Morgan company predicts global economic growth of $-1.1 \%$. Meanwhile, The Economist Intelligence Unit predicts global economic growth of $-2.2 \%$. World institutions are changing strategies to maintain global financial stability and allocating financing to deal with the Corona virus from various directions. In Indonesia, all economic sectors are predicted to experience a decline. The Ministry of Finance projects that GDP growth will fall to $2.3 \%$. The rupiah exchange rate against the dollar will increase to IDR 17,500 . The inflation rate could touch $3.9 \%$. The export sector can touch $14.00 \%$ and imports at $-14.50 \%$. The prediction of nominal GDP in 2020 could fall to IDR $16,829.8$ trillion [4].

In the Annex to Permenkeu 23 / PMK.03 / 2020 regarding Tax Incentives for Taxpayers affected by the Corona Virus Outbreak, it explains the facilities, incentives and calculation methods:

a. PPh Article 21 facilities borne by the Government (DTP) for 440 taxpayers' KLU.

b. Article 22 Import Income Tax Exemption Facility, Reduction of Article 25 Income Tax Installment and Preliminary Refund of VAT Payment for 102 Taxpayer KLU.

As one way to support the prevention and handling of the Corona virus in Indonesia. Permenkeu 23 / PMK.03 / 2020 concerning Tax Incentives for Taxpayers Affected by the Corona Virus Outbreak should be grateful considering the severity of the impact and the devastation of the world economy due to the impact of the COVID-19 [5]. The considerations of Permenkeu 23 / PMK.03 / 2020 regarding Tax Incentives for Taxpayers affected by the Corona Virus Outbreak are:

Which affect economic stability and productivity of certain sectors; 
b. that in order to maintain the stability of economic growth, people's purchasing power, and the productivity of certain sectors in connection with the Coronavirus Disease 2019 (COVID-19) outbreak as referred to in letter a, it is necessary to provide tax incentives in order to support the mitigation of the impact of the intended corona virus;

c. whereas based on the provisions of Article 6 letter e of Law Number 24 of 2007 concerning Disaster Management, the Government is responsible for disaster management including allocating adequate disaster management budget in the State Revenue and Expenditure Budget, as well as for implementing the provisions of Article 17C paragraph (7) and Article 17D paragraph (3) of Law Number 6 of 1983 concerning General Provisions and Tax Procedures as amended several times, most recently by Law Number 16 of 2009 concerning Stipulation of Government Regulations in Lieu of Law Number 5 of 2008 concerning the Fourth Amendment on Law Number 6 of 1983 concerning General Provisions and Procedures for Taxation into Law, Article 22 paragraph (2) and Article 25 of Law Number 7 of 1983 concerning Income Tax as amended several times, most recently by Law Number 36 of 2008 concerning the Fourth Amendment to Law Number 7 Tah un 1983 concerning Income Tax, and Article 9 paragraph (4d) of Law Number 8 of 1983 concerning Value Added Tax on Goods and Services and Sales Tax on Luxury Goods as amended several times, most recently by Law Number 42 of 2009 concerning Third Amendment to Law Number 8 of 1983 concerning Value Added Tax on Goods and Services and Sales Tax on Luxury Goods, it is necessary to regulate the provision of tax incentives for taxpayers affected by the corona virus outbreak;

d. that based on the considerations as referred to in letter a, letter b, and letter $c$, it is necessary to stipulate a Regulation of the Minister of Finance concerning Tax Incentives for Taxpayers Affected by the Corona Virus Outbreak [6]

Based on taxation theory, one of the tax functions is to raise state revenue and use it in development. However, the tax function can also provide regulations to help people in social and economic matters. Current tax incentives lead to regulatory functions with the aim of helping to move the wheels of the country's economy. Currently, Indonesia's economic condition is very worrying. The economy was running slowly, followed by the weak exchange rate of the rupiah against the United States dollar (Rp. 16,500 / US \$). On the other hand, people's purchasing power has also decreased. Therefore, in order to maintain the stability of economic growth, people's purchasing power as well as industrial productivity, the government issued regulations aimed at empowering the community. No exception with the tax aspect, a few days ago, on March 21, 2020, the Minister of Finance issued the PMK 23 / PMK-03/2020. This regulation is entitled Tax Incentives for Taxpayers Affected by the Corona Virus Outbreak.

The tax policy statement has been classified according to OECD data found that as many as 7 policies related to tax relief are directly related to corporate income tax, personal income tax and consumption tax in terms of import costs of consumer goods. Then each of 2 tax policies related to tax deferral and tax refunds. There is one tax policy that is very helpful for taxpayers, especially corporate taxpayers, in reducing the corporate income tax rate. This step is taken by the government to help and protect the taxpayer's business from the liquidation that in the future it will be even more severe. Tax-related policies, taken with the main objective by the government, are the basis that is affected by the COVID-19 pandemic, which is related to supporting the Health system which assists in handling and overcoming the COVID-19 pandemic outbreak. The government provides tax incentives for goods and services intended to tackle the COVID-19 pandemic, including value added tax, business income tax and import tax issued by PMK No. 28/2020. [7] 
PMK 23 / PMK03 / 2020 provides tax incentives on income tax (PPh) article 21, namely employee tax objects, income tax (PPh) article 22, namely the tax object on imports, income tax article 25, installments of tax and value added tax (VAT) in the event that accelerate the return (refund) of overpayed VAT. The limitation made in this regulation is for PPh 21 with the criteria for employees whose gross income is not more than 200 million rupiah per year or 16.6 million rupiah per month. Whereas for $\mathrm{PPh} 25$, the tax installment is reduced by $30 \%, \mathrm{PPh} 22$ is exempted, all of these incentives are valid for 6 months, starting from April 2020 [8].

However, not all business sectors receive this tax facility. Only certain industrial sectors and for taxpayers with the status of ease of import for export purposes (KITE) and KITE IKM, namely ease of import for export destinations for small and medium industries. If it describes the objectives of this regulation, for example for $\mathrm{PPh} 21$, so that workers in the management industry sector, especially factories with a significant number of employees, can maintain purchasing power. Meanwhile, $\mathrm{PPh} 22$ aims to provide a stimulus for the industry concerned to maintain its import rate. PPh 25 aims to stabilize the domestic economy and increase exports.

Regulations for accelerated VAT refunds aim to help taxpayers be more optimal in cash management and help taxpayers' cash flow amidst these difficulties. One of the tax functions is to raise state revenue and use it in development, but the tax function can also provide regulations to help people in social and economic matters. This Regulation of the Minister of Finance shows the positive aspects that are given to the public, especially to the business world, to keep it running. However, the government still needs to study to add new business sectors in order to get tax incentives. The new business sector that can receive this tax facility still needs to be expanded, because the impact of the Covid-19 pandemic is not only certain industrial sectors (management), KITE and KITE IKM. However, almost all sectors, including the service sector, the property sector, the tourism sector and many other business sectors have been hit at this time. The economy has a multiplier effect, such as a chain that is interrelated with one another. So if there is an economic downturn in some fields, this will automatically affect other sectors, either directly or indirectly. As with the tourism industry, it is experiencing a decline because at this time it is because most people (almost all) want to be at home to be safe from Covid-19 transmission. The tourism industry has many derivatives such as travel agencies, hotels, and restaurants in tourist attractions, as a result this sector is definitely drooping today.

One of the sectors that have experienced severe shocks due to the COVID-19 pandemic is the tourism sector [11]. According to KADIN, this blow was also experienced by derivatives of the tourism sector such as hotels, restaurants, transportation, airlines and this impact was also experienced by Micro, Small and Medium Enterprises (MSMEs). Whereas the tourism sector has an important role in the Indonesian economy [9]. Based on data on market expectations, the hotel industry experienced a decrease in total revenue due to the impact of the Covid-19 corona virus by minus $25 \%$ to minus $50 \%$, likewise the restaurant industry experienced a decrease in turnover by $25 \%$ to $50 \%$ compared to sales at the time. normal conditions. So from the data and arguments above, it is necessary to add a business sector variable that gets tax incentives for the Covid-19 pandemic, because all sectors are experiencing a decline and sluggishness. However, the tax incentive policy must be reviewed because this will significantly erode tax revenue. For example, $\mathrm{PPh} 21$ or $\mathrm{PPh}$ on employee income, in 2019 the actual revenue was IDR 148.63 trillion. If tax incentives are given for the $\mathrm{PPh} 21$, the state will lose quite a lot of its income. Indeed, it is expected that this will bounce off the increasing purchasing power of the community so that there will also be an increase in VAT receipts because people will consume goods, but the effect of this will not necessarily happen [10]. This condition is inversely proportional to the tax incentives that will reduce state income, currently the government needs a lot of funds to subsidize food, medicine as well as medical facilities to tackle Covid-19. So mature steps are 
needed in making policies, especially tax regulations so that they can have a positive impact on the economy of the people at large. However, to save the national economy, especially from the business sector, the provision of tax incentives is very helpful for entrepreneurs in solving taxation problems, especially in reducing the income tax burden, which in the current covid 19 pandemic, the entrepreneur's own income has decreased drastically and even threatens the sustainability of the business to continue being able. run.

\section{References}

[1] Nazara, Suahasil, (2020), The Government Gives Rp $220 \mathrm{~T}$ Tax Incentives for Entrepreneurs. Republika, accessed October 23, 2020, https://republika.co.id/berita/q0jiks383/pemerintah-beriinsentif-pajak-rp-220-t-untuk-pengusaha

[2] Directorate General of Taxes, (2020), The Importance of 'Tax Planning' When Starting a Business, accessed 23 October 2020, https://klikpajak.id/blog/perplan-pajak/tax-planning-saat-memulai-usaha/

[3] Mulyodiwarno, Nuryadi, (2020), Tax Incentives for Various Entrepreneurs, Academics: It's Complete, DDTC News, accessed October 23, 2020, https://news.ddtc.co.id/insentive-pajak-bagipengusaha- various-academics-already-complete-24363? page_y $=3325.60009765625$

[4] Directorate General of Taxes, (2020), These are Tax Incentives that Apply during the Covid 19 Pandemic, accessed October 23, 2020, https://www.online-pajak.com/st/seputar-efaktur-ppn/keb Policy-insentif- tax

[5] Directorate General of Taxes, (2020), These are Tax Incentives that Applied During the Covid 19 Pandemic, accessed October 24, 2020, https://www.online-pajak.com/st/seputar-efaktur-ppn/keb Policy-insentif- tax

[6] Government of Indonesia, (2020), Permenkeu 23 / PMK.03 / 2020 concerning Tax Incentives for Taxpayers Affected by the Corona Virus Outbreak. Accessed 23 October 2020, https://www.jogloabang.com/ekbis/permenkeu-23pmk032020-insentif-pajak-wajib-pajakterdampak-wabah-virus-corona

[7] Government of Indonesia, (2020), Permenkeu 23 / PMK.03 / 2020 concerning Tax Incentives for Taxpayers Affected by the Corona Virus Outbreak. Accessed 23 October 2020, https://www.jogloabang.com/ekbis/permenkeu-23pmk032020-insentif-pajak-wajib-pajakterdampak-wabah-virus-corona

[8] Padyanoor, Aswin, (2020), Indonesian Tax Policy Responding to the COVID-19 Crisis: Benefits for Taxpayers. Journal of Accounting, Vol. 30 No. 9, 2216-2230.

[9] Kartiko, Nafis Dwi, (2020), Tax Incentives in Responding to the Impact of the Covid-19 Pandemic on the Tourism Sector. PKN: journal of tax and state finance. Vol. 2 No.1, 124-147.

[10] Directorate General of Taxes, Government of Indonesia, (2020), https://www.onlinepajak.com/st/seputar-efaktur-ppn/keb Policy-insentif-pajak, 05 October 2020.

[11] Chrismonita, V. N., Dewi, D. A. S., Suharso, S., \& Budiharto, B. (2020). Efektivitas Permendagri Nomor 7 Tahun 2019 tentang Pelayanan Administrasi Kependudukan Secara Daring (Studi di Disdukcapil Kota Magelang dalam Rangka Mewujudkan Good Governance). Borobudur Law Review, 2(2), 64-89. 